\title{
Inhibition of the ecto-beta subunit of F1F0-ATPase inhibits proliferation and induces apoptosis in acute myeloid leukemia cell lines
}

Zhao Wen-Li ${ }^{1 \dagger}$, Wang Jian ${ }^{1 \dagger}$, Tao Yan-Fang ${ }^{1}$, Feng Xing ${ }^{1}$, Li Yan-Hong ${ }^{1}$, Zhu Xue-Ming ${ }^{1}$, Zhang Min ${ }^{1}$, Ni Jian ${ }^{2}$ and Pan Jian ${ }^{1 *}$

\begin{abstract}
Background: Leukemia, a heterogeneous clonal disorder of hematopoietic progenitor cells, presents a world-wide health problem, especially in childhood. F1F0 ATPase, an inner mitochondrial enzyme, is expressed on the plasma membrane of tumor cells, and its inhibition induces both anti-angiogenic and anti-tumorigenic activity.

Methods: Monoclonal Antibody (McAb) against ATPase was produced by polyethylene glycol-mediated fusions and screened by ELISA. Proliferation, cell cycle and apoptosis of cells were analyzed when the surface ATPase of cells was blockaded with McAb.

Results: We detected cell-membrane expression of the F1FO ATPase $\beta$ subunit on $0.1 \%$ to $56 \%$ of the 11 cell lines derived from leukemia, including acute myeloid leukemia (AML). We produced a monoclonal antibody, McAb7E10, which recognizes both the native and recombinant ATPase $\beta$ subunit, with a dissociation constant (KD) of $3.26 \mathrm{E}^{-10}$. We demonstrate that MCAb7E10 binds to ATPase at the cell surface, where it is able to inhibit ATP synthesis. McAb7E10 significantly inhibited proliferation of AML cell lines in vitro: the relative inhibitory rates of $50 \mu \mathrm{g} / \mathrm{mL}$ McAb7E10 treated MV4-11and HL-60 cells were $69.6 \%$ and $81.9 \%$ respectively. Cell cycle analysis indicated that McAb7E10 significantly induced apoptosis in MV4-11 and HL-60 cells: the relative rates of apoptosis in 5, 10 and $50 \mathrm{ug} / \mathrm{mL}$ McAb7E10 treated MV4-11 cells was $3.6 \pm 0.83 \%, 8.4 \pm 1.69 \%$ and $17.3 \pm 2.56 \%$ compared to $1.5 \% \pm 0.85 \%$ in mouse IgG treated cells $(p<0.01)$. The relative rate of apoptosis in 5,10 and $50 \mathrm{ug} / \mathrm{mL}$ McAb7E10 treated HL-60 cells was $5.5 \pm 2.37 \%, 11.3 \pm 3.62 \%$ and $19.9 \pm 3.31 \%$ compared to $1.56 \% \pm 0.97 \%$ in mouse lgG treated cells $(p<0.01)$. Annexin $\vee$ staining demonstrated that the relative apoptotic rates in $50 \mu \mathrm{g} / \mathrm{mL}$ McAb7E10 treated MV4-11 and $\mathrm{HL}-60$ cells were $50.5 \% \pm 7.04 \%$ and $32.9 \% \pm 4.52 \%$, respectively, significantly higher than IgG control antibody treated cells were $21.9 \% \pm 3.11 \%$ and $15.3 \% \pm 3.95 \%, p<0.01$.
\end{abstract}

Conclusions: These findings indicate that ectopic expression of ATPase $\beta$ subunit may be a tumor-associated antigen in hematological malignancies. The F1F0 ATPase $\beta$ subunit provides a potential target for immunotherapy in $\mathrm{AML}$ and hematological malignancies.

Keywords: Acute myeloid leukemia, Apoptosis, Ecto-ATPase $\beta$ subunit, Proliferation, HL-60, MV4-11

\footnotetext{
* Correspondence: panjian2008@163.com

${ }^{\dagger}$ Equal contributors

'Department of Hematology and Oncology, Children's Hospital of Soochow University, Suzhou, China

Full list of author information is available at the end of the article
} 


\section{Background}

F1F0 ATP synthase is a complex molecular motor responsible for the majority of ATP synthesis in all organisms [1,2]. The ATP synthase $\beta$ subunit is mostly expressed in the inner mitochondrial membrane of normal cells [3-9]. Over the last few years, reports by several independent groups have described the presence of various subunits of ATP synthase at the cell surface of mammalian cells, which have been termed ecto-F1F0ATPase $[5,10-13]$. Recent studies have shown that the $\beta$ subunits of F1F0 ATPase are located on the plasma membrane, as well as within the mitochondrial membrane of human vascular endothelial cells and tumor cells $[5,6,10,14]$. Most of the cell lines which are reported to express ecto-F1F0-ATPase $\beta$-subunits are leukemia cell lines, including K562, Raji [15], Daudi, U937 [11], Jurkat [16], ST-Emo and Rma-S [17].

In endothelial cells, the ecto-F1F0-ATPase $\beta$ subunit has been identified as a receptor for angiostatin, a naturally occurring inhibitor of angiogenesis [5,14] which inhibits endothelial cell proliferation, tube formation and migration. Several conflicting reports have debated whether ectoF1F0-ATPase is functional in tumor cells [3,10,15,17-20]. Recent data has shown that the mitochondrial F1ATPase is expressed on tumor cell surface and promotes tumor recognition by Vgamma9Vdelta2 $\mathrm{T}$ cells. [11]. T lymphocytes are known to participate in the immune response against various intracellular pathogens, including tumor cells. Additionally, other research has demonstrated that inhibition of the ecto-F1F0-ATPase $\beta$ subunit is directly cytotoxic to tumor cells $[3,18,21]$. This data indicates that identification of novel ecto-F1F0ATPase $\beta$ subunit inhibitors, with both anti-angiogenic and anti-tumorigenic activities, may confer a greater therapeutic advantage by affecting cancer cells via by multiple mechanisms with potentially additive effects.

In this study, we analyzed expression of the ecto-F1F0ATPase $\beta$ subunit in eleven cell lines derived from hematological malignancies and HUVECs, a positive control human vascular endothelial cell line. Most of cell lines derived from hematological malignancies expressed the ecto-F1F0-ATPase $\beta$ subunit. We produced a monoclonal antibody 7E10 (McAb7E10) specific to the human F1F0 ATPase $\beta$ subunit, which inhibited proliferation and induced significant apoptosis in the acute myeloid leukemia (AML) cell lines, MV4-11 and HL-60. These results suggest that the abnormal cell surface expression of the ecto-F1F0-ATPase $\beta$ subunit may provide a potential target for cancer immunotherapy in hematological malignancies, particularly AML.

\section{Methods}

\section{Cell culture}

Cell lines derived from hematological malignancies (HL60, MV4-11, U937, K562, Raji, and Jurkat) were obtained from the American Type Culture Collection (ATCC). SHI-1, MOLT4, DAMI, CCRF and 697 cell lines (gifts from Professor Wang Jian-Rong, The Cyrus Tang Hematology center of Soochow University). The entire cell lines were maintained at $37^{\circ} \mathrm{C}$ in the RPMI 1640 supplemented with $10 \%$ fetal bovine serum, $100 \mathrm{U} / \mathrm{ml}$ penicillin and $100 \mathrm{mg} / \mathrm{ml}$ streptomycin [22]. HUVEC cells were a gift from Professor Yang Zhi-Hua (Department of Cell and Molecular Biology, Cancer Institute, Chinese Academy of Medical Sciences, Beijing, China) and were cultured in M200 basal culture media supplemented with low serum growth supplement (Cascade Biologics, PL, USA), $100 \mathrm{U} / \mathrm{ml}$ penicillin and $100 \mathrm{mg} / \mathrm{ml}$ streptomycin [23-25]. All cells were cultured at $37^{\circ} \mathrm{C}$ in a $5 \% \mathrm{CO}_{2}$ humidified atmosphere.

\section{Flow cytometric assay}

Cells were collected, washed twice with phosphate buffered saline (PBS), adjusted to $1 \times 10^{6}$ cells $/ \mathrm{ml}$, and incubated with ATP synthase subunit beta monoclonal antibody (1:300; MitoScience MS503, EA, USA) for $30 \mathrm{~min}$ at $4^{\circ} \mathrm{C}$. After washing three times with PBS, fluorescein-isothiocyanate (FITC)-labeled goat antimouse IgG (Jackson,WG, PA) diluted in PBS was added, incubated for $20 \mathrm{~min}$ at $4^{\circ} \mathrm{C}$, then cells were washed three times with PBS, $1 \mathrm{ug} / \mathrm{ml}$ PI(Propidium Iodide, Sigma, St. Louis, MO, USA)) was added to exclude the dead cells and membrane antigen expression was analyzed using a fluorescence-activated cell sorter (ESP Elite, Beckman Coulter, Fullerton, CA, USA). All experiments were performed three times.

\section{Production of functional F1F0 ATPase $\beta$ subunit antibody}

Six to eight weeks old female BALB/c mice were subcutaneously immunized with hATP5B (F1F0 ATPase $\beta$ subunit) which had been expressed using a prokaryotic system, as previously described [3], and mixed with Freund's complete adjuvant (Sigma, St. Louis, MO, USA). The antibody valences in peripheral blood were determined using an ELISA as Gou, L. T. described [21], and three days after the last boost, $5 \times 10^{8}$ sensitized spleen cells were harvested, mixed and fused with $1 \times$ $10^{8} \mathrm{SP} 2 / 0$ myeloma cells, in $50 \%$ polyethylene glycol 1500 in a proportion of $8: 1$. The fused cells were plated in 96-well plates $\left(6 \times 10^{5} /\right.$ well $)$ and cultured for two weeks in RPMI 1640 with $10 \%$ fetal calf serum containing hypoxanthine, aminopterin, and thymidine to select for positive hybrid cells. The positive hybridoma cells were subcloned by limiting dilution, and 10-12 week old female BALB/c mice were inoculated with $3 \times 10^{6}$ hybridoma cells $[3,26]$. The antibodies were further purified from the ascites via Protein-A affinity chromatography [3]. The antibody with the highest valence against the 
F1F0 ATPase $\beta$ subunit was named as McAb7E10 and used in further experiments.

\section{Western blotting and BIAcore analysis}

Cellular proteins were extracted in $40 \mathrm{mM}$ Tris- $\mathrm{HCl}$ (pH 7.4) containing $150 \mathrm{mM} \mathrm{NaCl}$ and $1 \%(\mathrm{v} / \mathrm{v})$ Triton $\mathrm{X}-100$ and supplemented with a cocktail of protease inhibitors. Equal amounts of protein were resolved on $12 \%$ SDS-PAGE gels then transferred to a PVDF membrane. After blocking with 5\% non-fat milk, the membranes were incubated with McAb7E10 antibody overnight at $4^{\circ} \mathrm{C}$, then with HRP-conjugated sheep antimouse IgG secondary antibody (Vector, Burlingame, CA, USA). After washing, the protein bands were visualized using the SuperEnhanced chemiluminescence detection kit (Applygen Technologies Inc., Beijing, China) and Xray film (Kodak,NY,USA). The binding and dissociation kinetics of McAb7E10 with the recombinant ATPase $\beta$ subunit were determined using a BIAcore surface plasmon resonance instrument (Pharmacia, Uppsala, Sweden) [27-31]. Briefly, $1400 \mathrm{RU}$ of the recombinant ATPase $\beta$ subunit $(25 \mathrm{ug} / \mathrm{mL}$ in $10 \mathrm{mmol} / \mathrm{L}$ sodium acetate, $\mathrm{pH}$ 4.5) were covalently bound through amino groups to a CM5 sensor chip [32-34].

\section{ATPase activity assay}

$1^{*} 10^{4}$ cells per well were equilibrated with serum-free medium at $37^{\circ} \mathrm{C}$ with $5 \% \mathrm{CO}_{2}$ overnight, respectively, in 96-well plates. Then the cells were treated with different concentrations of McAb7E10, oligomycin (Sigma, St. Louis, MO, USA), a known inhibitor of ATPase F1 or mouse IgG for $30 \mathrm{~min}$. The cells were then incubated with adenosine diphosphate (Sigma, St. Louis, MO, USA) for $60 \mathrm{~s}$, and supernatants were removed and assayed for ATP production using a bioluminescence assay kit (Invitrogen, Carlsbad, CA, USA). Samples were injected with the ATP assay mixture (Promega, Madison, WI, USA) and incubated for $10 \mathrm{~min}$ to stabilize the luminescence signal. Recordings were made in an Analyst HT (Molecular Devices, Sunnyvale, CA, USA) over a 20 s period. Data are expressed as moles of ATP per well based on standards determined under the same conditions during each experiment.

\section{Cell proliferation assay}

Acute myeloid leukemia (AML) cells (MV4-11 and HL60) were seeded in 96-well plates at 50,000 cells per well and $5-50 \mathrm{ug} / \mathrm{mL}$ mouse control IgG or $5-50 \mathrm{ug} / \mathrm{mL}$ McAb7E10 antibody was added. After 24, 48, 72, 96 or $120 \mathrm{~h}, 20 \mu \mathrm{L} 5 \mathrm{mg} / \mathrm{ml}$ MTT (3-(4,5-dimethylthiazol-2yl)-2,5- diphenyltetrazolium bromide) solution was added to each well, incubated at $37^{\circ} \mathrm{C}$ for $4 \mathrm{~h}$, then the media was removed and $200 \mu \mathrm{L}$ dimethylsulfoxide (DMSO) was added. Optical density (OD) values were measured at $490 \mathrm{~nm}$ using a scanning multi-well spectrophotometer (BioRad Model 550, Hercules, CA, USA), and the survival rates of McAb7E10 treated cells were calculated relative to the control antibody treated cells. All experiments were performed in triplicate and repeated twice. The results were analyzed using ANOVA and the Student-Newman-Keuls tests, $p<0.05$ were considered significant.

\section{Cell cycle analysis}

Cells were harvested and a single cell suspension was prepared in buffer (PBS $+2 \% \mathrm{FBS})$, washed twice and adjusted to $1 \times 10^{6}$ cells $/ \mathrm{ml}$. Aliquots of $1 \mathrm{ml}$ cell suspension were placed in $15 \mathrm{ml}$ polypropylene $\mathrm{V}$ bottomed tubes and $3 \mathrm{ml}$ cold absolute ethanol was added to fix the cells for at least $1 \mathrm{~h}$ at $4^{\circ} \mathrm{C}$. Cells were washed twice in PBS, $1 \mathrm{ml}$ propidium iodide staining solution was added to the cell pellet, mixed well, and $50 \mu \mathrm{l}$ RNAse A stock solution was added and incubated for $3 \mathrm{~h}$ at $4^{\circ} \mathrm{C}$ before flow cytometry analysis was performed.

\section{Cell apoptosis analysis}

Cell apoptosis was analyzed using the Annexin V-FITC Apoptosis Detection Kit (Cat. No 556570; BD Franklin Lakes, NJ, USA) according to the manufacturer's instructions. Briefly, incubated with mouse IgG or McAb7E10 antibody for 48 hours, then cells were washed twice with cold PBS, resuspended in 1x Binding Buffer at $1 \times 10^{6}$ cells $/ \mathrm{ml}$ and a $100 \mu \mathrm{l}\left(1 \times 10^{5}\right.$ cells $)$ aliquot was transferred to a $5 \mathrm{ml}$ culture tube. $5 \mu \mathrm{l}$ Annexin $\mathrm{V}$ and $10 \mu \mathrm{l}$ vital dye was added, gently mixed, incubated for $15 \mathrm{~min}$ at RT in the dark, then $400 \mu \mathrm{l}$ of 1x Binding Buffer was added to each tube and immediately analyzed by flow cytometry. All experiments were performed three times.

\section{Statistical analysis}

All data are presented as mean \pm SD. Statistical analysis was performed using SPSS statistical software (SPSS Inc, Chicago, IL, USA), $p \leq 0.05$ were considered significant.

\section{Results and discussion}

The ecto-ATPase $\beta$ subunit is expressed in cell lines from hematologic malignancies

The ATP synthase $\beta$ subunit is known to be constitutively expressed in the inner mitochondrial membrane of normal cells, and ectopically expressed in primary cultured endothelial cells [3-7]. Liver carcinoma cells and lung carcinoma cells also express the ATP synthase $\beta$ subunit on their cell surface $[18,21]$. In this study, we found that the ATP synthase $\beta$ subunit is upregulated and ectopically expressed on the cell surface of human AML cells. Using flow cytometry, the $\beta$ 
subunit of F1F0 ATPase was detected in 11 leukemia cell lines (two ALL cell lines 697 and Jurkat; three lymphoma cell lines CCRF, Raji and MOLT4; six myeloid leukemia cell lines MV4-11, SHI-1,DAMI, K562, HL-60 and U937). MV4-11, HL-60 and Jurkat are the top three cells (Figure 1). The $\beta$ subunit of F1F0 ATPase was also detected in the positive control HUVEC cell line (Figure 1). The number of cells expressing ecto-ATPase $\beta$ subunit on the cell membrane ranged from $0.1 \%$ to $56 \%$. The percentage of cells expressing ecto-ATPase $\beta$ subunit on the cell membrane in the K562 cell line (17.2\%), derived from a 53 year old female CML patient, and the monocytic cell line U937 (18.6\%), were similar to the previous report of Scotet E et al. [11].

\section{Production and characterization of McAb7E10}

In order to generate a monoclonal antibody (McAb) against the natural epitopes of the ATPase catalytic subunit, we immunized BALB/c mice with both natural
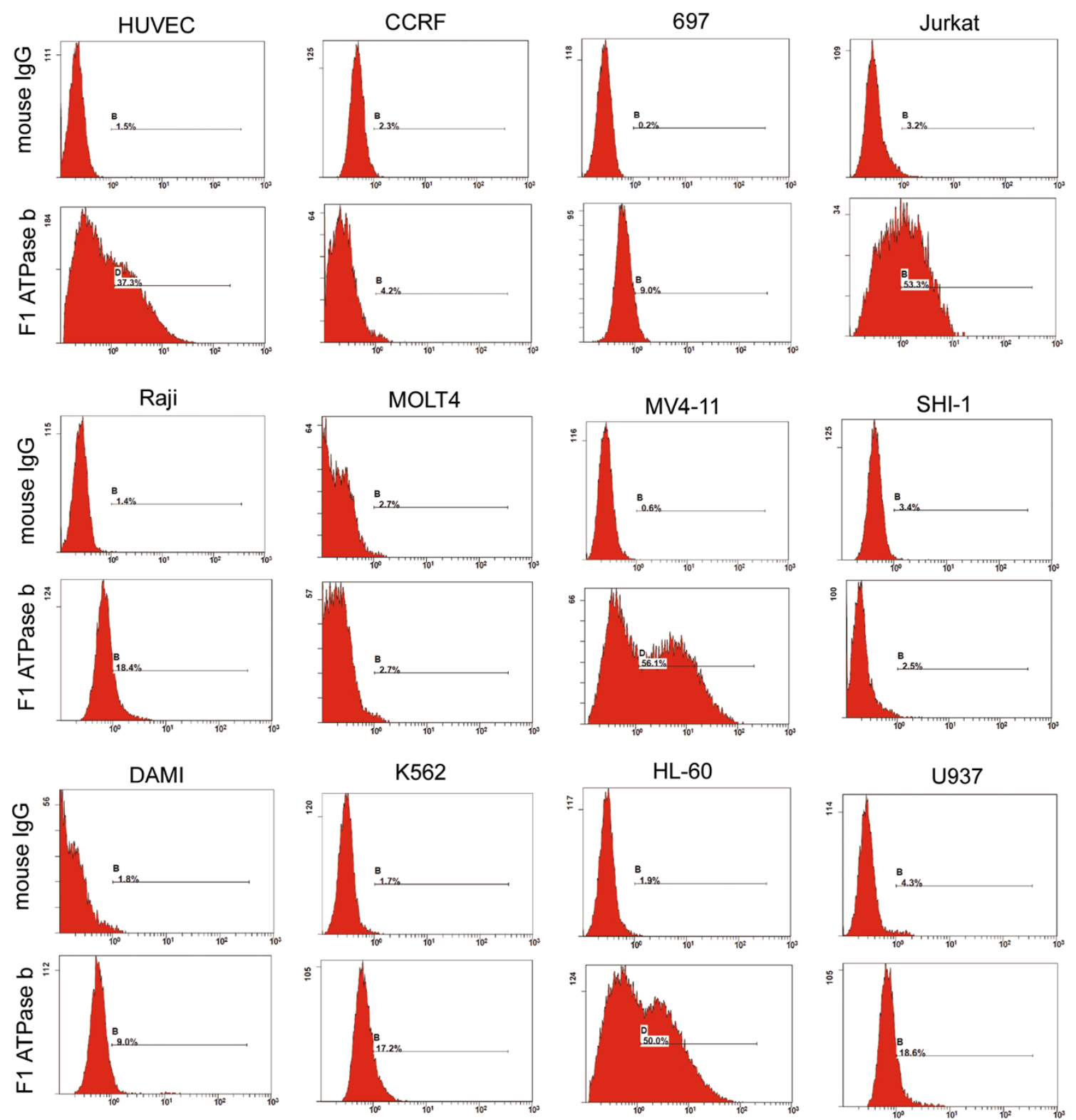

Figure 1 Expression of ecto-ATPase $\beta$ subunit in cell lines from hematological malignancies. Cells were collected, incubated with an ATP synthase subunit $\beta$ monoclonal antibody or mouse IgG control antibody, then with fluorescein-isothiocyanate (FITC)-labeled goat anti-mouse IgG and membrane ATP synthase subunit $\beta$ expression was analyzed using fluorescence activated cell sorting (FACS). FACS results of 11 leukemia cells and HUVEC cells incubated with control lgG and ATP synthase subunit $\beta$ monoclonal antibody. 
immunogen and the human ATPase $\beta$ subunit, which had been expressed in prokaryotes. After several fusion experiments, hundreds of monoclonal hybridoma cells were obtained. One immunoglobulin G1 (IgG1) hybridoma clone, named McAb7E10, recognized both the native and recombinant ATPase $\beta$ subunit. In Western blot analysis, the McAb7E10 antibody identified a single band corresponding to the molecular mass of the ATPase $\beta$ subunit, and did not cross react with the ATPase $\alpha$ subunit (Figure 2A). The affinity of McAb7E10 to the recombinant ATPase $\beta$ subunit was evaluated using BIAcore, and the dissociation constant was $\mathrm{KD}_{\mathrm{McAb7E} 10}=3.26 \mathrm{E}^{-10}$ (Figure $2 \mathrm{~B}$ ), which is higher than the $\mathrm{KD}$ of $4.24 \mathrm{E}^{-9}$ of the previously characterized ATPase $\beta$ subunit antibody McAb178-5 G10 [3].

\section{McAb7E10 inhibits cell surface ATP generation in AML cells}

To examine the inhibitory effect of the antibody on ATP synthesis, a cell surface ATP generation assay was performed. Results showed that McAb7E10 antibody significantly inhibited ATP synthesis in AML cells. The relative inhibitory rates in 25, 50 and $100 \mathrm{ug} / \mathrm{mL}$ McAb7E10 treated MV4-11 cells were 14.1\%, 23.1\% and $25.0 \%$, in HL-60 cells were $16.1 \%, 28.1 \%$ and $29.3 \%$ respectively (Figure 3A, 3B). The maximal inhibition of McAb7E10 to MV4-11 and HL-60 cells was $~ 30 \%$ $(300 \mu \mathrm{g} / \mathrm{mL})$, and the maximal inhibition of oligomycin to both cells was $\sim 80 \%(300 \mu \mathrm{g} / \mathrm{mL})$.

\section{McAb7E10 inhibits AML cell proliferation and induces apoptosis in AML cells}

This study provides evidence that McAb7E10 preferentially binds to the cell surface ATPase $\beta$ subunit, and can inhibit cell proliferation and induce apoptosis in MV4-11 and HL-60 AML cells. The effect of McAb7E10 on the proliferation of MV4-11 and HL-60 cells was evaluated using the MTT assay. Compared to control mouse IgG treated cells, after $120 \mathrm{~h}$, the relative inhibitory rates in 5, 10 and $50 \mathrm{ug} / \mathrm{mL}$ McAb7E10 treated MV4-11 cells were $24.5 \%, 44 \%$ and $69.6 \%$, respectively (Figure 3C). After $120 \mathrm{~h}$, the relative inhibitory rates in 5, 10 and 50 $\mathrm{ug} / \mathrm{mL}$ McAb7E10 treated HL-60 cells were $39.4 \%, 62.1 \%$ and $81.9 \%$, respectively (Figure 3D). These results indicate that McAb7E10 can significantly inhibit the proliferation of AML cells in vitro.

Using cell cycle analysis and Annexin V staining, a subpopulation of cells before the G1 population was detected after treatment with McAb7E10, indicating cells with abnormal nuclei which can be considered to be apoptotic and dead cells. The relative rate of apoptosis in 5, 10 and $50 \mathrm{ug} / \mathrm{mL}$ McAb7E10 treated MV4-11 cells was $3.6 \pm 0.83 \%, 8.4 \pm 1.69 \%$ and $17.3 \pm 2.56 \%$ compared to $1.5 \% \pm 0.85 \%$ in mouse IgG treated cells $(p<0.01$, Figure $4 \mathrm{~A}, 4 \mathrm{~B})$. The relative rate of apoptosis in 5,10 and $50 \mathrm{ug} / \mathrm{mL}$ McAb7E10 treated HL-60 cells was $5.5 \pm 2.37 \%, 11.3 \pm 3.62 \%$ and $19.9 \pm 3.31 \%$ compared to $1.56 \% \pm 0.97 \%$ in mouse IgG treated cells $(p<0.01$, Figure 4A, 4C). To determine whether McAb7E10 can
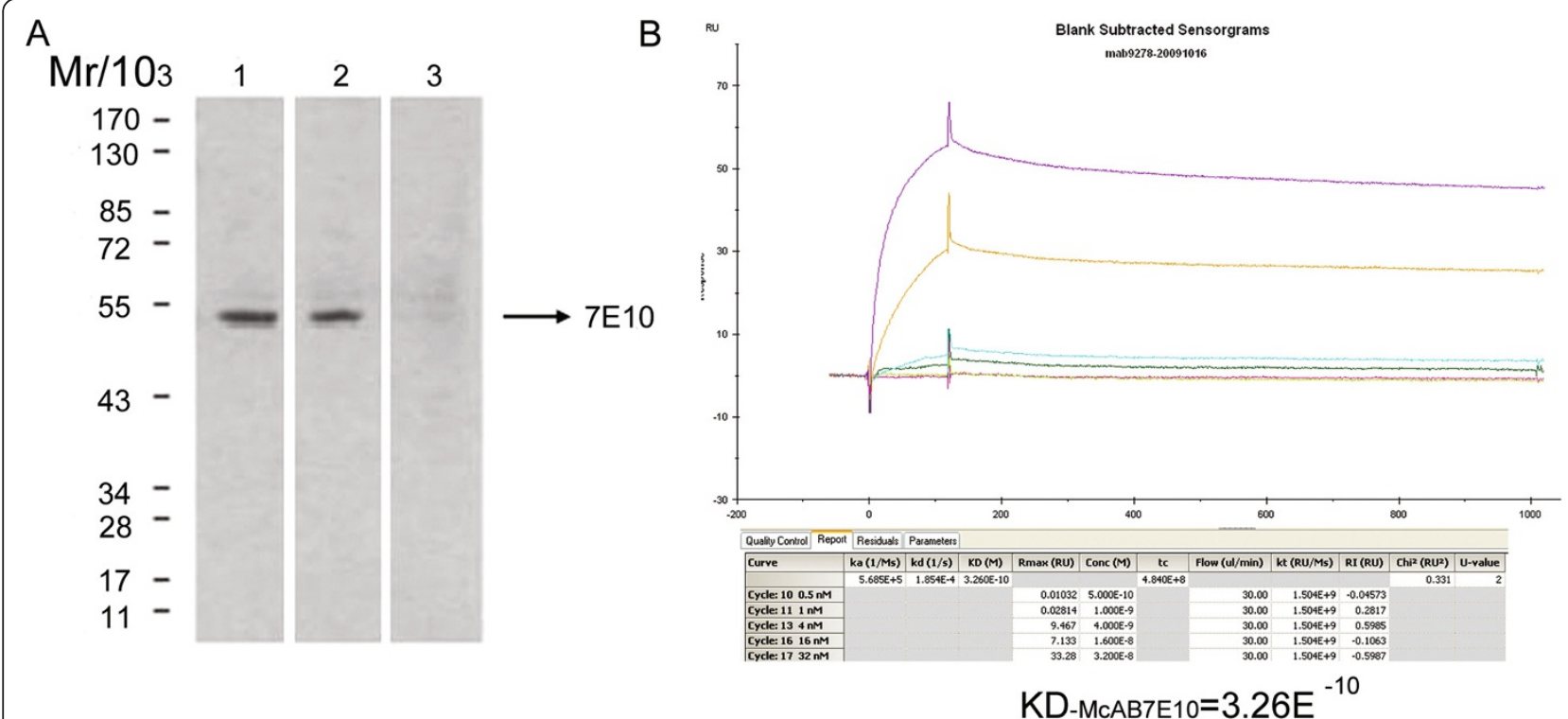

Figure 2 Production and characterization of McAb7E10. A monoclonal antibody with a high valency against F1F0 ATPase $\beta$ subunit was developed and named MCAb7E10. (A) In Western blot analysis, the MCAb7E10 antibody detected a single immunoreactive band in HUVEC protein lysate (lane 1) and recombinant ATPase $\beta$ subunit protein (lane 2), but did not detect recombinant human ATPase a subunit protein (lane3). (B) The affinity of McAb7E10 to recombinant ATPase $\beta$ subunit was evaluated using BIAcore. The affinity of McAb7E10 to the recombinant ATPase $\beta$ subunit was evaluated using BIAcore, and the dissociation constant was $\mathrm{KD}_{\mathrm{McAb} \text { E10 }}=3.26 \mathrm{E}^{-10}$. 

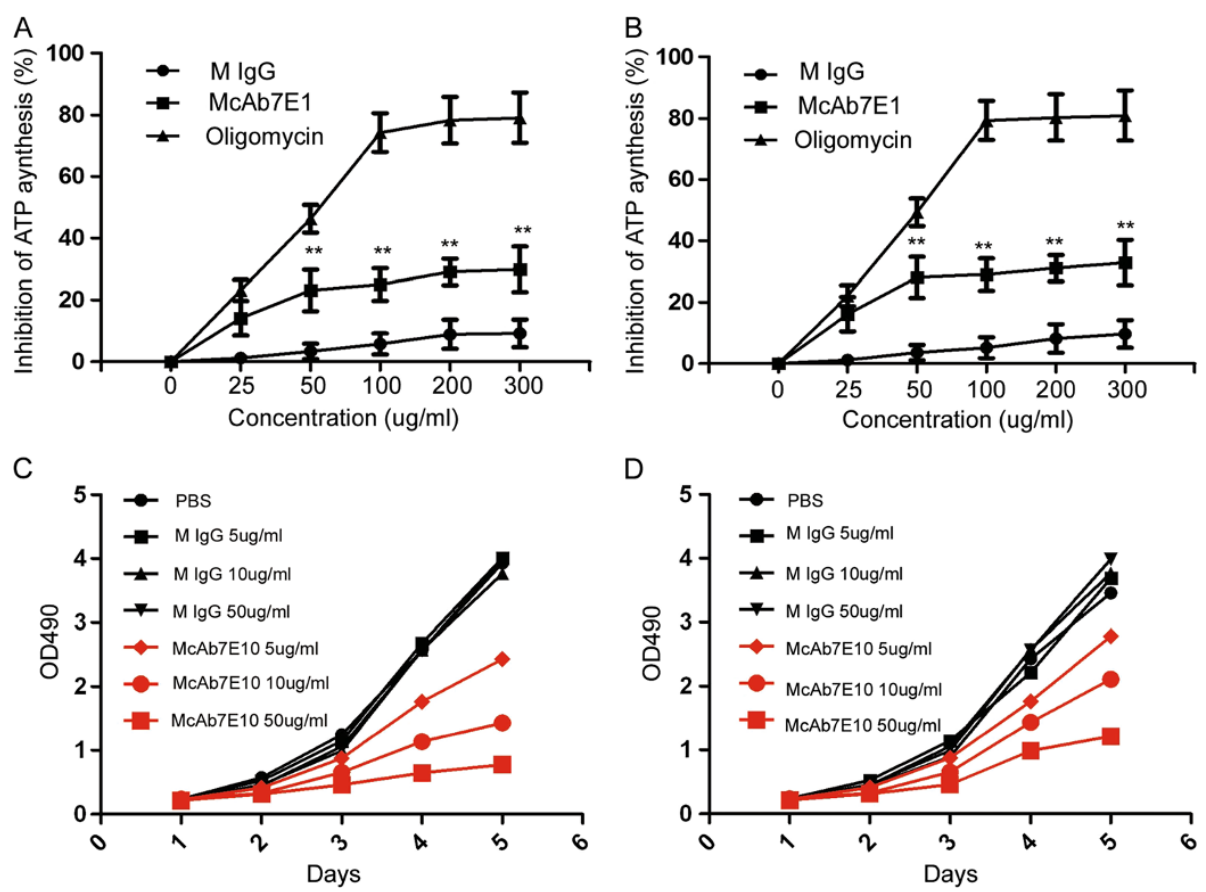

Figure 3 McAb7E10 inhibits cell surface ATP generation and proliferation in AML cell. To examine the inhibitory effect of the antibody on ATP synthesis, a cell surface ATP generation assay was performed. Results showed that McAb7E10 antibody significantly inhibited ATP synthesis in AML cells. The effect of McAb7E10 on the proliferation of the AML cell lines MV4-11 and HL-60 was evaluated using the MTT assay. (A, B) ATP generation on the surface of MV4-11 (A) and HL-60 (B) cells is inhibited dose-dependently in the presence of McAb7E10 and oligomycin. Oligomycin, a known inhibitor of ATP synthase F1, was used as positive control and mouse lgG as negative control. Data represent means \pm SD. (C) Proliferation analysis of MV4-11 cells treated with mouse IgG and McAb7E10. At $120 \mathrm{~h}$, the relative inhibitory rates for 5, $10 \mathrm{and} 50 \mathrm{\mu g} / \mathrm{mL}$ McAb7E10 treated MV4-11 cells were 24.5\%, 44\% and 69.6\% respectively, compared to control mouse IgG treated cells. (D) Proliferation analysis of HL-60 cells treated with mouse IgG and McAb7E10. At $120 \mathrm{~h}$, the relative inhibitory rates for 5, 10 and $50 \mathrm{\mu g} / \mathrm{mL}$ McAb7E10 treated HL-60 cells were $39.4 \%, 62.1 \%$ and $81.9 \%$ respectively, compared to control mouse lgG treated cells.

induce apoptosis of leukemia cells, we test the apoptosis of cells with Annexin V test Kit. The data showed that the relative apotosis rate of 50ug/ml McAb7E10 treated MV4-11 cells was $50.5 \% \pm 7.04 \%$ vs mouse IgG treated cells was $21.9 \% \pm 3.11 \% \mathrm{P}<0.01$ (Figure $5 \mathrm{~A}-\mathrm{C}$ ). The relative apotosis rate of $50 \mathrm{ug} / \mathrm{ml} \mathrm{McAb7E10} \mathrm{on} \mathrm{HL-60}$ cells was $32.9 \% \pm 4.52 \%$ vs mouse IgG treated cells was $15.3 \% \pm 3.95 \% P<0.01$ (Figure 5D).

\section{ATPase $\beta$ subunit inhibition provides a target for immuotherapy in hematologic malignancies}

The cell surface ATPase $\beta$ subunit acts as a high-density lipoprotein (HDL) receptor, through binding of apolipoprotein A-I in hepatocytes, and also regulates lipoprotein internalization in endothelial cells [21]; however the effects downstream of the cell surface ATPase $\beta$ subunit remain to be determined. ATPase $\beta$ subunits have been detected on the membrane of tumor cells, raising the possibility that the structure of the $\beta$ subunit protein on the cell surface may perform a different function to the inner mitochondrial protein structure. Our findings indicate that ectopic expression of the ATPase $\beta$ subunit is a tumor-associated antigen in hematological malignancies.
Although the function of the cell surface ATPase $\beta$ subunit requires further study, this study implies that the ATPase $\beta$ subunit plays an important role in cancer cell proliferation and apoptosis. Our findings are in agreement with previous studies which have indicated that angiostatin, plasminogen kringle 1-5 (K1-5), McAb against the ATPase $\beta$ subunit $[3,35]$ and small molecular inhibitors $[1,36]$ can bind to ATP synthase on the cell surface and inhibit endothelial cell proliferation, migration, trigger apoptosis [3-6,10,14,19].

Cell surface ATP synthase is more active at a low extracellular $\mathrm{pH}$ [21]; therefore, ectopic expression of the ATPase $\beta$ subunit may play an important role in the survival of cells suffering an energy shortage or during treatment with chemotherapy drugs, indicating cell surface ATP synthase may play important role in the development and treatment resistance of hematological malignancies. Our study suggests that abnormal cell surface expression of ecto-F1F0-ATPase $\beta$ subunit may provide a potential target for cancer immunotherapy in hematological malignancies.

F1F0 ATP synthase was recently reported to be a cochaperone of heat shock protein Hsp90, as F1F0 ATP 

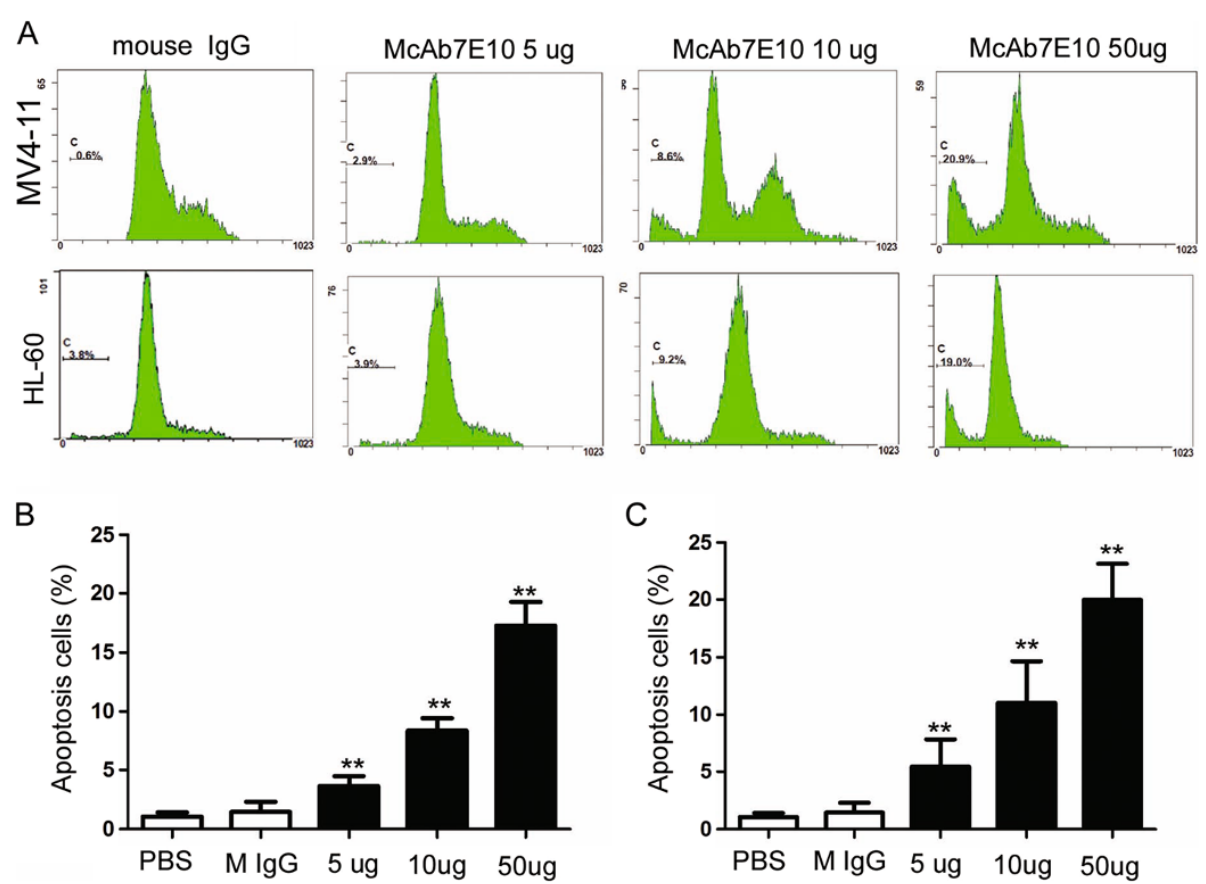

Figure 4 Analysis of effect of McAb7E10 on the cell cycle in AML cell lines. Cells were harvested, fixed, stained with propidium iodide staining and analyzed by flow cytometry. (A) Cell cycle analysis results of MV4-11 and HL-60 cell treated with different dose of McAb7E10. (B) The relative rate of apoptosis in 5, 10 and $50 \mathrm{ug} / \mathrm{mL}$ MCAb7E10 treated MV4-11 cells was $3.6 \pm 0.83 \%, 8.4 \pm 1.69 \%$ and $17.3 \pm 2.56 \%$ compared to $1.5 \%$ $\pm 0.85 \%$ in mouse lgG treated cells, $p<0.01$. (C) The relative rate of apoptosis in 5,10 and $50 \mathrm{ug} / \mathrm{mL}$ MCAb7E10 treated HL-60 cells was $5.5 \pm$ $2.37 \%, 11.3 \pm 3.62 \%$ and $19.9 \pm 3.31 \%$ compared to $1.56 \% \pm 0.97 \%$ in mouse lgG treated cells, $p<0.01$.
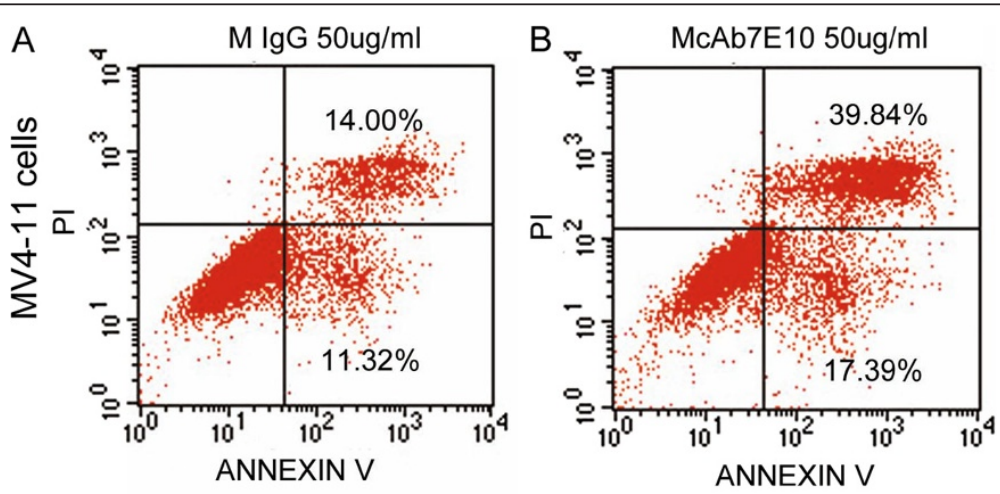

C

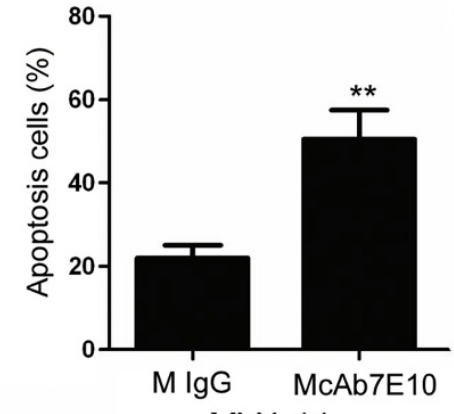

MV4-11

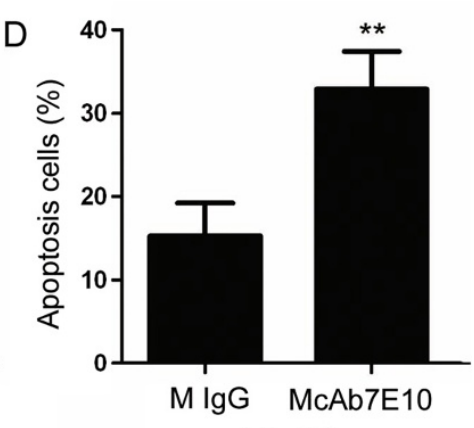

$\mathrm{HL}-60$

Figure 5 McAb7E10 induces apoptosis in AML cell lines. (A, B) Annexin V staining and flow cytometry was used to confirm that McAb7E10 induced apoptosis in AML cells. (C) The relative rate of apoptosis in $50 \mu \mathrm{g} / \mathrm{ml}$ McAb7E10 treated MV4-11 cells was $50.5 \% \pm 7.04 \%$ vs $21.9 \% \pm$ $3.11 \%$ in mouse $\mathrm{lgG}$ treated cells, $p<0.01$. (D) The relative rate of apoptosis in $50 \mathrm{\mu g} / \mathrm{ml} \mathrm{McAb7E10} \mathrm{treated} \mathrm{HL-60} \mathrm{cells} \mathrm{was} 32.9 \% \pm 4.52 \%$ vs $15.3 \% \pm 3.95 \%$ in mouse lgG treated cells, $p<0.01$. 
synthase co-immunoprecipitates with Hsp90 and Hsp90client proteins in cell lysate from MCF-7, T47D, MDAMB-453 and HT-29 cancer cells [37]. Heat shock proteins are often overexpressed in human malignancies, including AML. Hsp90 is the major chaperone required for stabilization of the multiple oncogenic kinases involved in the development of AML [38]. Hsp90 client proteins are also involved in the regulation of apoptosis, proliferation, autophagy and cell cycle progression, and several hsp90 client proteins are considered to be possible therapeutic targets for the treatment of AML [39]. Hsp90 inhibitors could be used as single agents or potentially, in combination with other targeted treatments such as a functional ATP synthase $\beta$ subunit antibody. This study indicates that clinical focus of hsp90 inhibitors and F1F0-ATP $\beta$ subunit synthase functional antibodies should be directed towards hematological malignancies, as well as solid tumors and malignant melanoma.

\section{Conclusions}

This study demonstrates that the $\beta$ subunit of F1F0 ATPase is expressed on the cell surface of several leukemia cell lines with between $0.1 \%$ and $56 \%$ of cells expressing the ecto-F1F0-ATPase $\beta$ subunit. We prepared a McAb against the ecto-F1F0-ATPase $\beta$ subunit, which significantly inhibited proliferation and induced apoptosis in cell lines derived from AML in vitro. These findings indicate that expression of the ecto-F1F0ATPase $\beta$ subunit is a cancer-associated antigen in hematological malignancies. The ecto-F1F0-ATPase $\beta$ subunit provides a potential target for immunotherapy in AML and other hematological malignancies.

\section{Abbreviations}

ELISA: Enzyme-linked immunosorbent assay; McAb: Monoclonal antibody; AML: Acute myeloid leukemia.

\section{Competing interests}

The authors have no conflicts of interest to disclose.

\section{Authors' contributions}

PJ designed and directed the study. ZWL, WJ and TYF finished the most of the experiments. FX and LYH drafted this manuscript. ZXM and ZM participated in the cell culture. NJ participated in study design and coordination, data analysis and interpretation and drafted the manuscript. All authors read and approved the final manuscript.

\footnotetext{
Acknowledgements

We thank Professor Zhi-Hua Yang (Cancer Institute/Cancer Hospital, Chinese Academy of Medical Sciences and Peking Union Medical College, Beijing, China) for her kindly instruction.

This work was supported by grants from the National Key Basic Research Program No. 2010CB933902, National Natural Science Foundation for youth No. 81100371, Natural Science Foundation of Jiangsu Province No. BK2011308, Universities Natural Science Foundation of Jiangsu Province No. $11 \mathrm{KJB} 320014$ and Talent's subsidy project in science and education of department of public health of Suzhou City No. SWKQ1020. Medical innovation team and leading talent of Jiangsu Province. No. L201126. Major scientific and technological special project for "significant new drugs creation" No. 2012ZX09103301-040
}

\section{Author details}

'Department of Hematology and Oncology, Children's Hospital of Soochow University, Suzhou, China. ${ }^{2}$ Translational Research Center, Second Hospital, The Second Clinical School, Nanjing Medical University, Nanjing, China.

Received: 7 August 2012 Accepted: 5 November 2012 Published: 9 November 2012

\section{References}

1. Valenti D, Tullo A, Caratozzolo MF, Merafina RS, Scartezzini P, Marra E, Vacca RA: Impairment of F1F0-ATPase, adenine nucleotide translocator and adenylate kinase causes mitochondrial energy deficit in human skin fibroblasts with chromosome 21 trisomy. Biochem J 2010, 431:299-310.

2. Percy JM, Pryde JG, Apps DK: Isolation of ATPase I, the proton pump of chromaffin-granule membranes. Biochem J 1985, 231:557-564.

3. Zhang X, Gao F, Yu LL, Peng Y, Liu HH, Liu JY, Yin M, Ni J: Dual functions of a monoclonal antibody against cell surface F1F0 ATP synthase on both HUVEC and tumor cells. Acta Pharmacol Sin 2008, 29:942-950.

4. Chi SL, Wahl ML, Mowery YM, Shan S, Mukhopadhyay S, Hilderbrand SC, Kenan DJ, Lipes BD, Johnson CE, Marusich MF, et al: Angiostatin-like activity of a monoclonal antibody to the catalytic subunit of F1F0 ATP synthase. Cancer Res 2007, 67:4716-4724.

5. Moser TL, Stack MS, Asplin I, Enghild JJ, Hojrup P, Everitt L, Hubchak S, Schnaper HW, Pizzo SV: Angiostatin binds ATP synthase on the surface of human endothelial cells. Proc Natl Acad Sci U S A 1999, 96:2811-2816.

6. Radojkovic C, Genoux A, Pons V, Combes G, de Jonge H, Champagne E, Rolland C, Perret B, Collet X, Terce F, Martinez LO: Stimulation of cell surface F1-ATPase activity by apolipoprotein A-I inhibits endothelial cell apoptosis and promotes proliferation. Arterioscler Thromb Vasc Biol 2009, 29:1125-1130

7. Zick M, Rabl R, Reichert AS: Cristae formation-linking ultrastructure and function of mitochondria. Biochim Biophys Acta 2009, 1793:5-19.

8. Plaza H, Whelchel TR, Garczynski SF, Howerth EW, Gherardini FC: Purified outer membranes of Serpulina hyodysenteriae contain cholesterol. J Bacteriol 1997, 179:5414-5421.

9. Bienen EJ, Saric M, Pollakis G, Grady RW, Clarkson AB Jr: Mitochondrial development in Trypanosoma brucei brucei transitional bloodstream forms. Mol Biochem Parasitol 1991, 45:185-192.

10. Moser TL, Kenan DJ, Ashley TA, Roy JA, Goodman MD, Misra UK, Cheek DJ, Pizzo SV: Endothelial cell surface F1-F0 ATP synthase is active in ATP synthesis and is inhibited by angiostatin. Proc Natl Acad Sci U S A 2001, 98:6656-6661

11. Scotet E, Martinez LO, Grant E, Barbaras R, Jeno P, Guiraud M, Monsarrat B, Saulquin $X$, Maillet $S$, Esteve JP, et al: Tumor recognition following Vgamma9Vdelta2 $\mathrm{T}$ cell receptor interactions with a surface F1-ATPaserelated structure and apolipoprotein A-I. Immunity 2005, 22:71-80.

12. Yonally SK, Capaldi RA: The F(1)F(0) ATP synthase and mitochondrial respiratory chain complexes are present on the plasma membrane of an osteosarcoma cell line: An immunocytochemical study. Mitochondrion 2006, 6:305-314

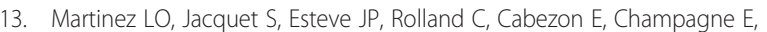
Pineau T, Georgeaud V, Walker JE, Terce F, et al: Ectopic beta-chain of ATP synthase is an apolipoprotein A-I receptor in hepatic HDL endocytosis. Nature 2003, 421:75-79.

14. Chi SL, Pizzo SV: Angiostatin is directly cytotoxic to tumor cells at low extracellular $\mathrm{pH}$ : a mechanism dependent on cell surface-associated ATP synthase. Cancer Res 2006, 66:875-882.

15. Das B, Mondragon MO, Sadeghian M, Hatcher VB, Norin AJ: A novel ligand in lymphocyte-mediated cytotoxicity: expression of the beta subunit of $\mathrm{H}+$ transporting ATP synthase on the surface of tumor cell lines. J Exp Med 1994, 180:273-281.

16. von Haller PD, Donohoe S, Goodlett DR, Aebersold R, Watts JD: Mass spectrometric characterization of proteins extracted from Jurkat T cell detergent-resistant membrane domains. Proteomics 2001, 1:1010-1021.

17. Vantourout P, Martinez LO, Fabre A, Collet X, Champagne E: Ecto-F1ATPase and MHC-class I close association on cell membranes. Mol Immunol 2008, 45:485-492.

18. Wang J, Han Y, Liang J, Cheng X, Yan L, Wang Y, Liu J, Luo G, Chen X, Zhao $L$, et al: Effect of a novel inhibitory mAb against beta-subunit of F1F0 ATPase on HCC. Cancer Biol Ther 2008, 7:1829-1835.

19. Cortes-Hernandez P, Dominguez-Ramirez L, Estrada-Bernal A, MontesSanchez DG, Zentella-Dehesa A, de Gomez-Puyou MT, Gomez-Puyou A, 
Garcia JJ: The inhibitor protein of the F1F0-ATP synthase is associated to the external surface of endothelial cells. Biochem Biophys Res Commun 2005, 330:844-849.

20. Wojtczak L: The Crabtree effect: a new look at the old problem. Acta Biochim Pol 1996, 43:361-368.

21. Lu ZJ, Song QF, Jiang SS, Song Q, Wang W, Zhang GH, Kan B, Chen LJ, Yang JL, Luo F, et al: Identification of ATP synthase beta subunit (ATPB) on the cell surface as a non-small cell lung cancer (NSCLC) associated antigen. BMC Cancer 2009, 9:16

22. Jian P, Li ZW, Fang TY, Jian W, Zhuan Z, Mei LX, Yan WS, Jian N: Retinoic acid induces HL-60 cell differentiation via the upregulation of miR-663. J Hematol Oncol 2011, 4:20.

23. Jian P, Yanfang T, Zhuan Z, Jian W, Xueming Z, Jian N: MMP28 (epilysin) as a novel promoter of invasion and metastasis in gastric cancer. BMC Cancer 2011, 11:200

24. Pan J, Hu H, Zhou Z, Sun L, Peng L, Yu L, Sun L, Liu J, Yang Z, Ran Y: Tumor-suppressive mir-663 gene induces mitotic catastrophe growth arrest in human gastric cancer cells. Oncol Rep 2010, 24:105-112.

25. Ran Y, Pan J, Hu H, Zhou Z, Sun L, Peng L, Yu L, Sun L, Liu J, Yang Z: A novel role for tissue factor pathway inhibitor- 2 in the therapy of human esophageal carcinoma. Hum Gene Ther 2009, 20:41-49.

26. Mowery YM, Pizzo SV: Targeting cell surface F1F0 ATP synthase in cancer therapy. Cancer Biol Ther 2008, 7:1836-1838.

27. Ahmed FE, Wiley JE, Weidner DA, Bonnerup C, Mota H: Surface plasmon resonance (SPR) spectrometry as a tool to analyze nucleic acid-protein interactions in crude cellular extracts. Cancer Genomics Proteomics 2010, 7:303-309.

28. Biswas KB, Nabi AH, Arai Y, Nakagawa T, Ebihara A, Ichihara A, Watanabe T, Inagami T, Suzuki F: Aliskiren binds to renin and prorenin bound to (pro) renin receptor in vitro. Hypertens Res 2010, 33:1053-1059.

29. Sahlan M, Zako T, Tai PT, Ohtaki A, Noguchi K, Maeda M, Miyatake $H_{\text {, }}$ Dohmae N, Yohda M: Thermodynamic characterization of the interaction between prefoldin and group II chaperonin. J Mol Biol 2010, 399:628-636.

30. Fukui M, Hinode D, Yokoyama M, Tanabe S, Yoshioka M: Salivary immunoglobulin A directed to oral microbial GroEL in patients with periodontitis and their potential protective role. Oral Microbiol Immunol 2006, 21:289-295.

31. Zhou H, Xu Y, Yang Y, Huang A, Wu J, Shi Y: Solution structure of AF-6 PDZ domain and its interaction with the C-terminal peptides from Neurexin and Bcr. J Biol Chem 2005, 280:13841-13847.

32. Hu C, Gan N, Chen Y, Bi L, Zhang X, Song L: Detection of microcystins in environmental samples using surface plasmon resonance biosensor. Talanta 2009, 80:407-410.

33. Situ C, Wylie AR, Douglas A, Elliott CT: Reduction of severe bovine serum associated matrix effects on carboxymethylated dextran coated biosensor surfaces. Talanta 2008, 76:832-836.

34. Rowe PS, Garrett IR, Schwarz PM, Carnes DL, Lafer EM, Mundy GR, Gutierrez GE: Surface plasmon resonance (SPR) confirms that MEPE binds to PHEX via the MEPE-ASARM motif: a model for impaired mineralization in X-linked rickets (HYP). Bone 2005, 36:33-46.

35. Aggeler R, Coons J, Taylor SW, Ghosh SS, Garcia JJ, Capaldi RA, Marusich MF: A functionally active human F1F0 ATPase can be purified by immunocapture from heart tissue and fibroblast cell lines. Subunit structure and activity studies. J Biol Chem 2002, 277:33906-33912.

36. Grover GJ, Malm J: Pharmacological profile of the selective mitochondrial F1F0 ATP hydrolase inhibitor BMS-199264 in myocardial ischemia. Cardiovasc Ther 2008, 26:287-296.

37. Papathanassiu AE, MacDonald NJ, Bencsura A, Vu HA: F1F0-ATP synthase functions as a co-chaperone of Hsp90-substrate protein complexes. Biochem Biophys Res Commun 2006, 345:419-429.

38. Reikvam H, Ersvaer E, Bruserud O: Heat shock protein 90 - a potential target in the treatment of human acute myelogenous leukemia. Curr Cancer Drug Targets 2009, 9:761-776.

39. Banerji U: Heat shock protein 90 as a drug target: some like it hot Clin Cancer Res 2009, 15:9-14.

doi:10.1186/1756-9966-31-92

Cite this article as: Wen-Li et al: Inhibition of the ecto-beta subunit of F1F0-ATPase inhibits proliferation and induces apoptosis in acute myeloid leukemia cell lines. Journal of Experimental \& Clinical Cancer Research 2012 31:92.

\section{Submit your next manuscript to BioMed Central and take full advantage of:}

- Convenient online submission

- Thorough peer review

- No space constraints or color figure charges

- Immediate publication on acceptance

- Inclusion in PubMed, CAS, Scopus and Google Scholar

- Research which is freely available for redistribution 